Iranian Journal of Forensic Medicine - ISSN 2383-0034

\title{
Review the Opinions of Physicians in the Country Concerning the Causes of Diagnostic Medical Errors
}

\author{
Abdolrazagh Barzegar ${ }^{1}$, Abbas Ali Vashian ${ }^{2 *}$, Hamid Sedighi Akha ${ }^{3}$
}

1. MD, Assistant Professor, Forensic Medicine Specialist, Legal Medicine Research Center, Legal Medicine Organization, Tehran, Iran

2. PhD in Quran \& Science (Hygiene \& Health), Member of Department of Medical Ethics, Legal Medicine Organization, Tehran, Iran

3. MD, Forensic Medicine Specialist, Legal Medicine Research Center, Legal Medicine Organization, Tehran, Iran

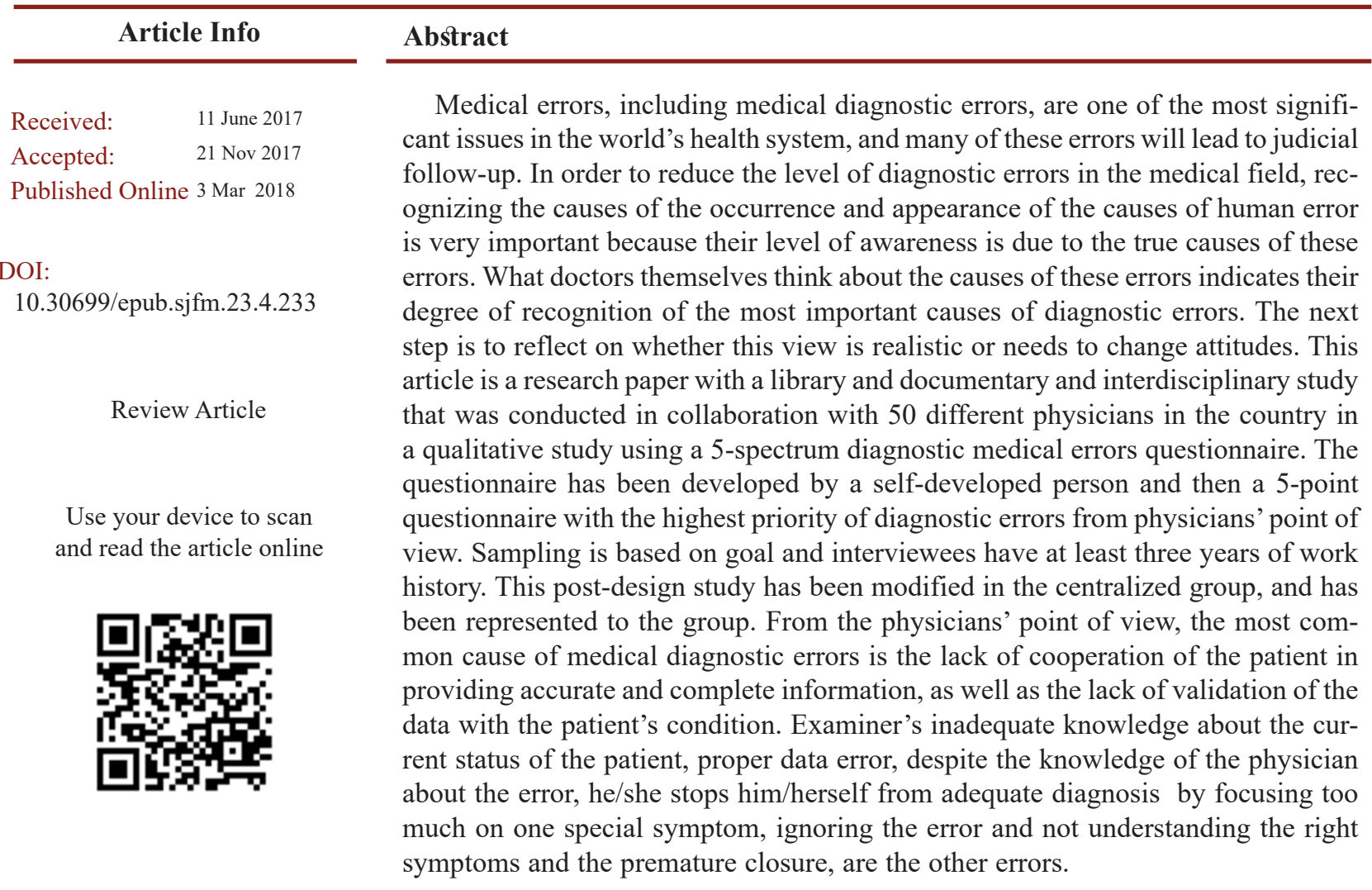

Keywords: Error, Diagnose, Diagnostic Medical Errors

Dr. AbbasAli Vashian, PhD in Quran \& Science (Hygiene \& Health), Member of Department of Medical Ethics, Legal Medicine Organization, Tehran, Iran Email: sadra251@gmail.com, Tel: 02538901758

Copyright (C 2018, Ir J Forensic Med. This is an open-access article distributed under the terms of the Creative Commons Attribution-noncommercial 4.0 International License which permits copy and redistribute the material just in noncommercial usages, provided the original work is properly cited.

How to Cite This Article:

Barzegar A, Vashian A A, Sedighi Akha H. Review the Opinions of Physicians in the Country Concerning the Causes of Diagnostic Medical Errors . Ir J Forensic Med. 2018; 23(4):233-241. 


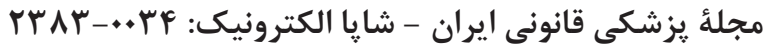

مقالئ مرورى إن إيا

بررسى نظرات يزشكان كشور در خصوص علل بروز خطاهاى تشخيصى يزشكى

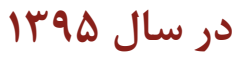

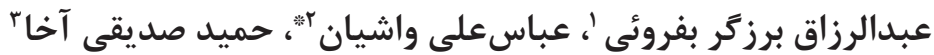

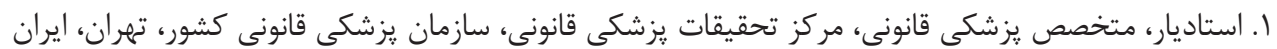

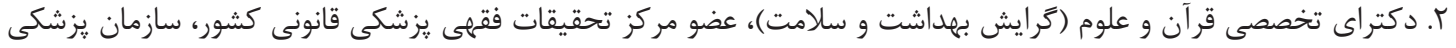

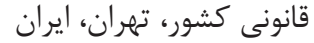

r. متخصص يزشكى قانونى، مركز تحقيقات يزشكى قانونى، سازمان يزشكى قانونى كشور، تهران، ايران

\begin{tabular}{|c|c|}
\hline جكيده & اطلاعات مقاله \\
\hline 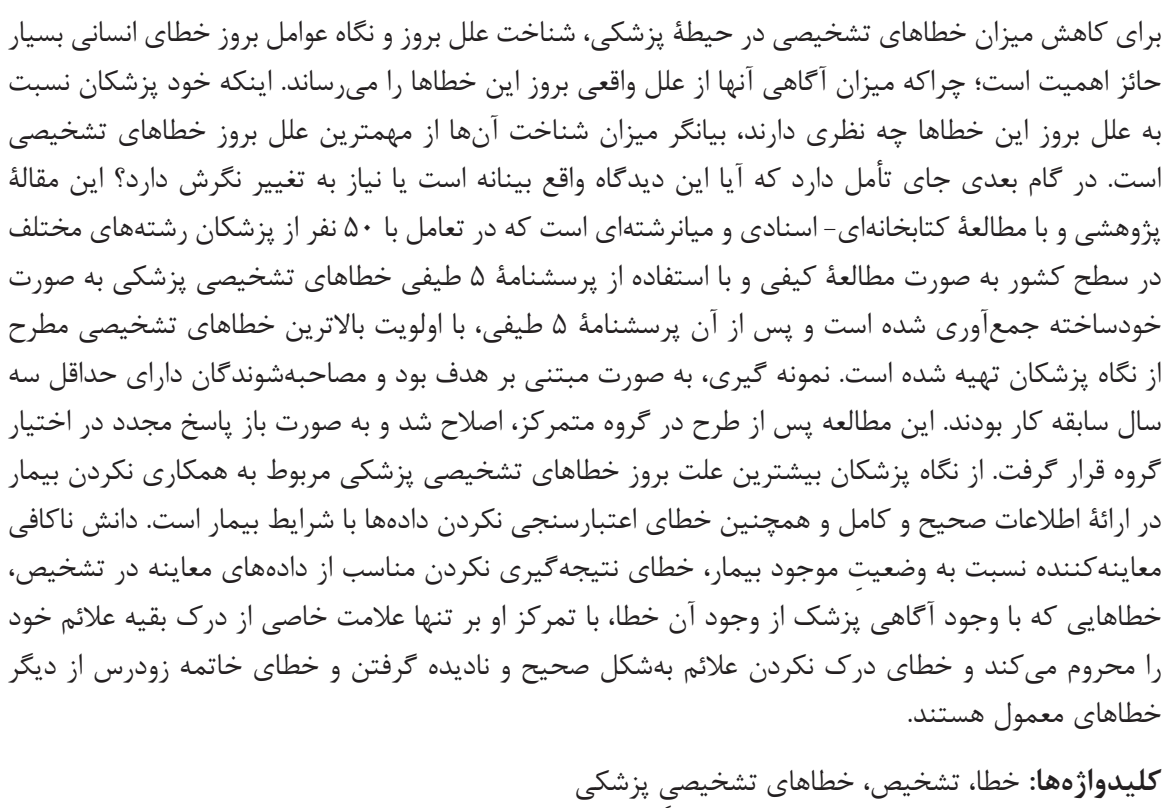 & 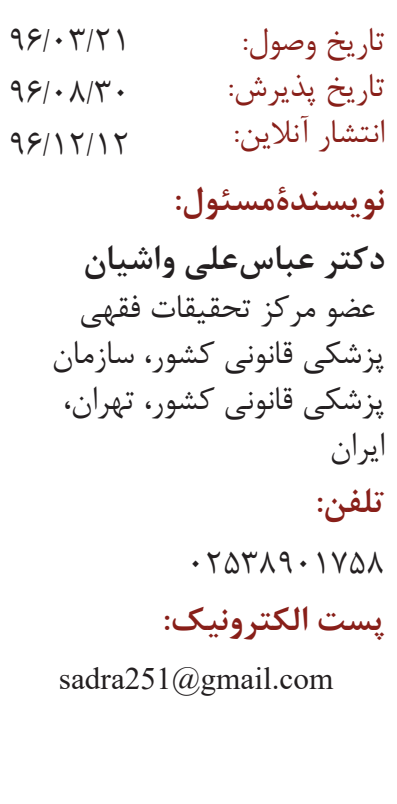 \\
\hline
\end{tabular}




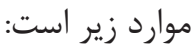

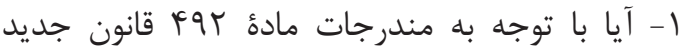

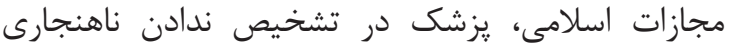

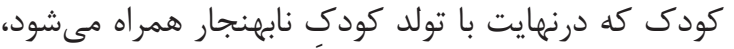
ضامن است؟ با در نظر داشتن اينكه علت نابت ناهنجارى

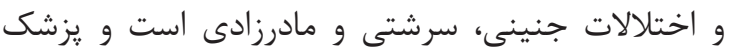

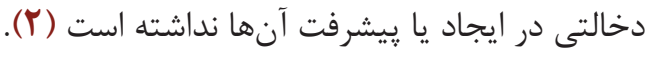
ץ- آيا تفاوتى بين اين دو حالت وجود دارد؛ در حالتى تردي

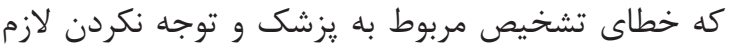

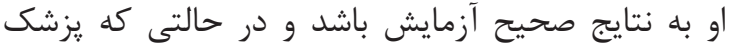

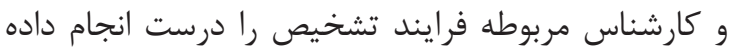

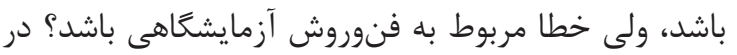

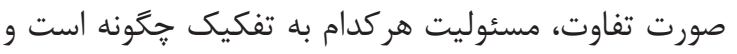

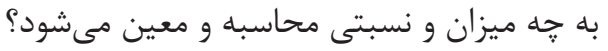

\section{1- مفهومشناسى خطاى تشخيصى غزشكى}

خطا در لغت به معناى سهو، اشتباه (ب)، لغزش، غلط،

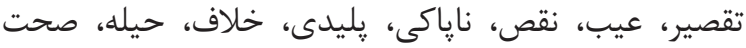

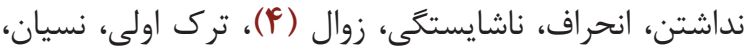

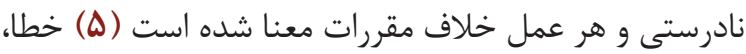

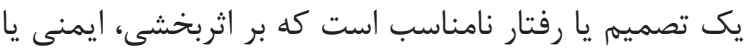

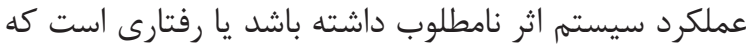

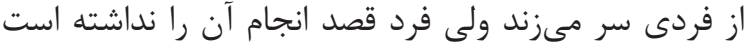

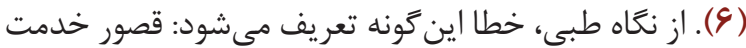

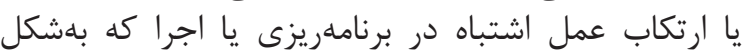

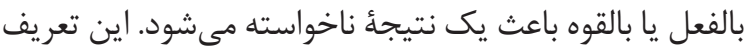

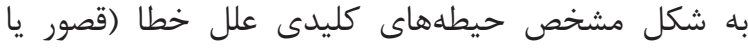

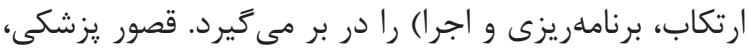

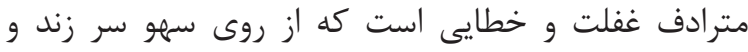

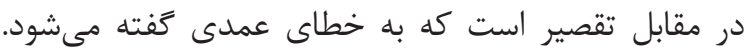

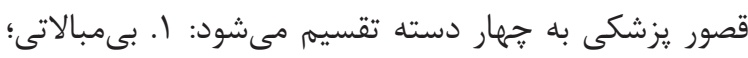

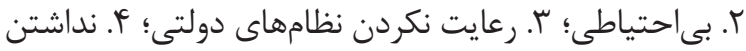

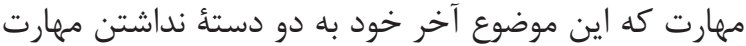

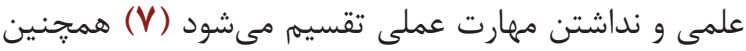

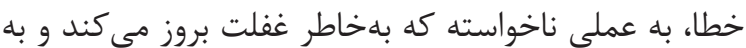

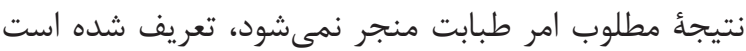

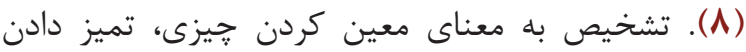

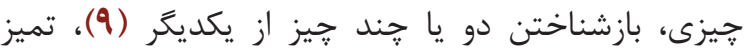

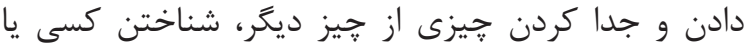

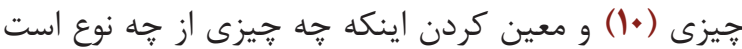

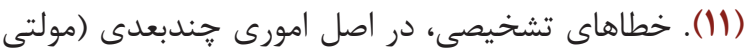

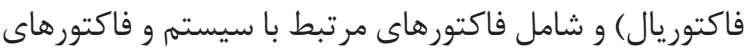

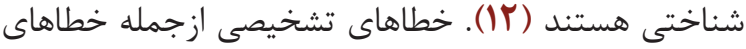

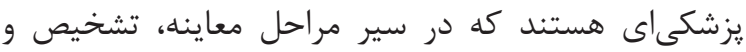

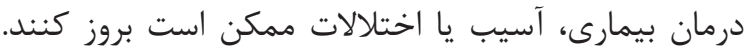

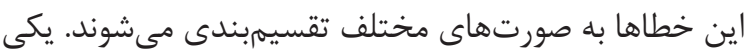

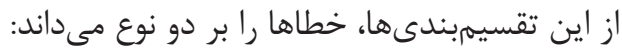

\section{مقدمه}

دقت، مهارت و يايبندى به اصول حرفهاى در يزشكى،

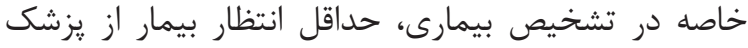

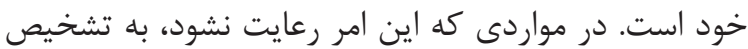

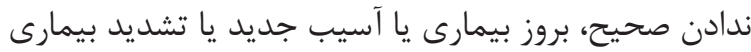

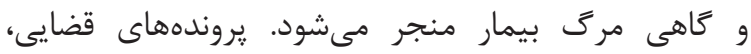

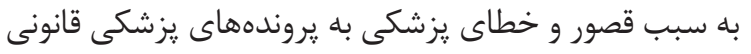

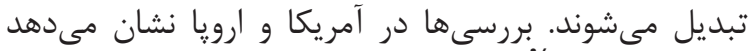

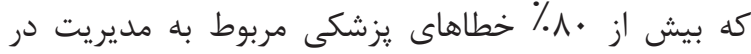

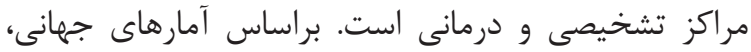

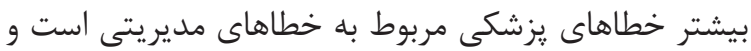

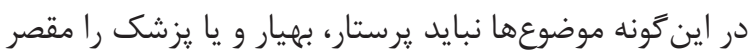

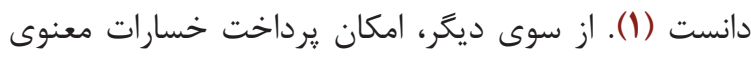

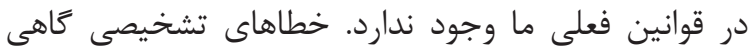

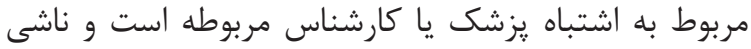

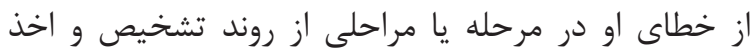

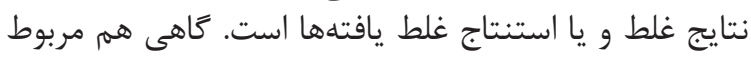

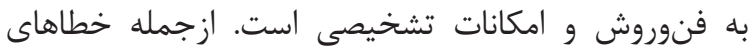

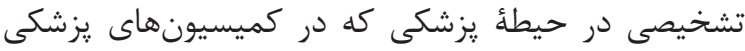

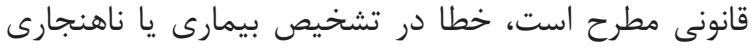

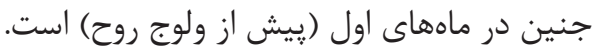

در رِاسخ به اين سؤال كه شناخت موضوعى خطاهاى

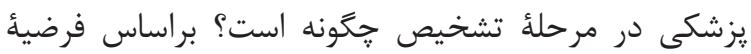

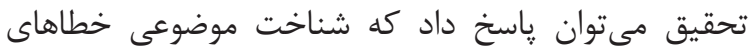

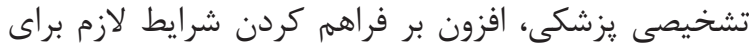

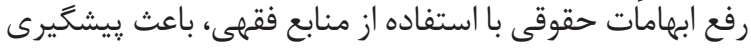

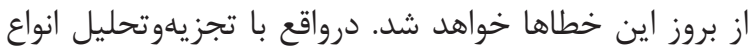

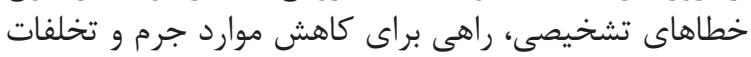

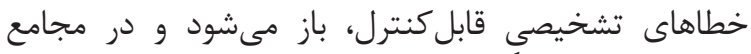

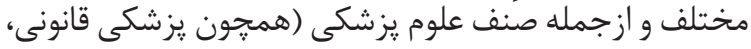

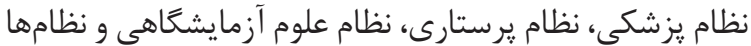

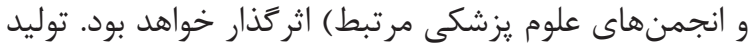

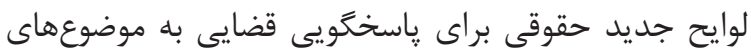

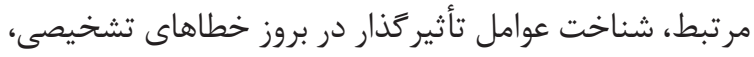

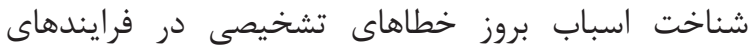

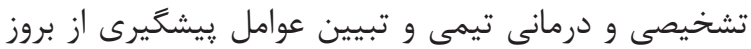

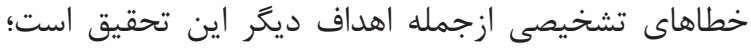

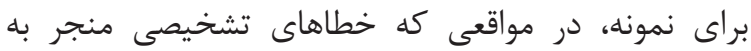

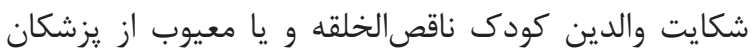

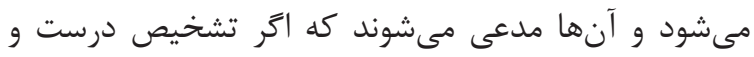

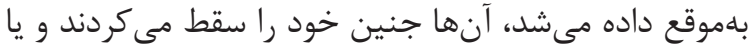
هزينهاهاى كودك بيمار و ناهنجار به داده آنها

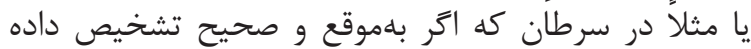

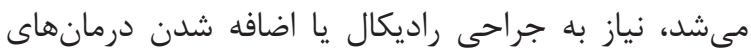

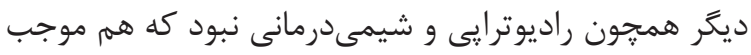

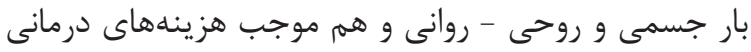
و حمايتى مى شود.

ضرورت اين تحقيق ياسخ گفتن به سؤالهايى همجون 


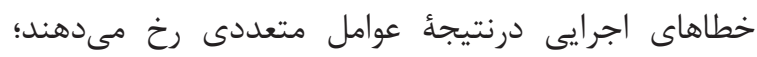

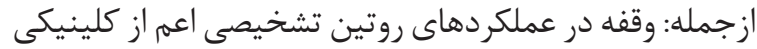

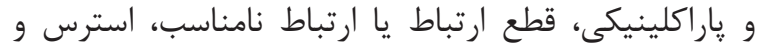

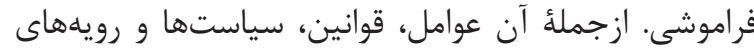

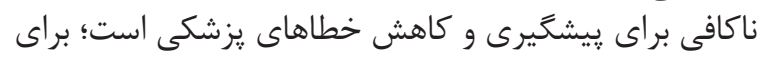

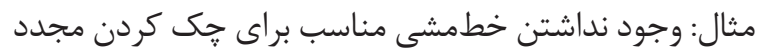

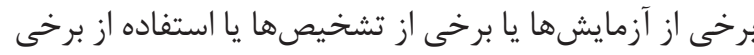

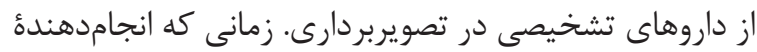

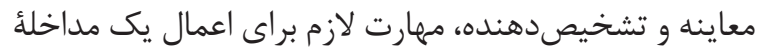

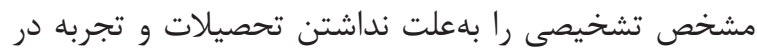

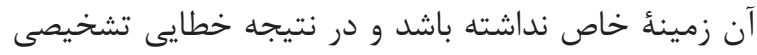

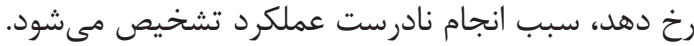

\section{r ب- طبقهبندى خطاهاى تشخيصى يز شكى بر اساس

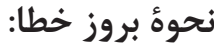

طبقلهبندى ديخرى كه براى خطاهاى تشخيصى مى توان

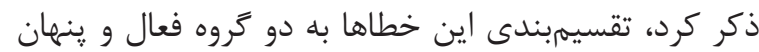

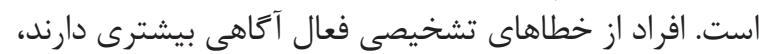

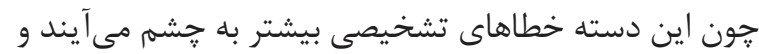

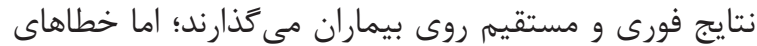

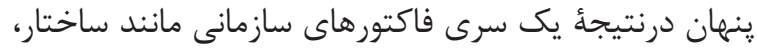

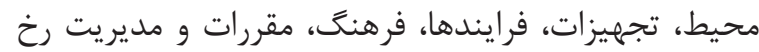

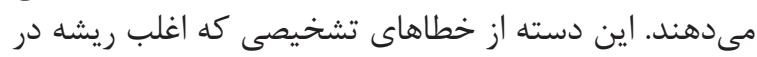

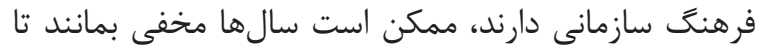

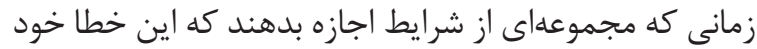

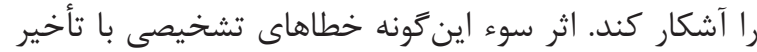

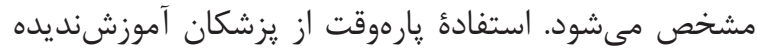

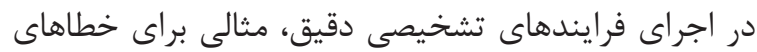

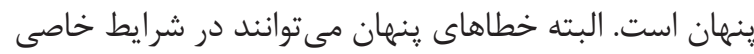

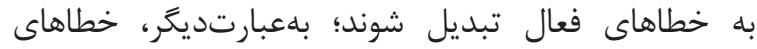

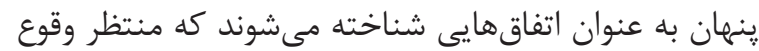

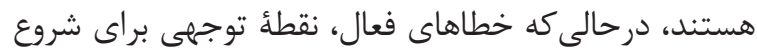

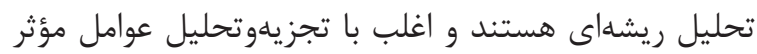
در وقوع خطا به روش تحليل ريشهاى وقايع (Root Case Control شناسايى مىشوند.

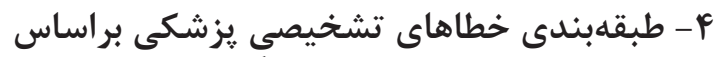

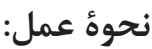

طبقهبندى ديخر در ارتباط با خطاهاى تشخيصى آن

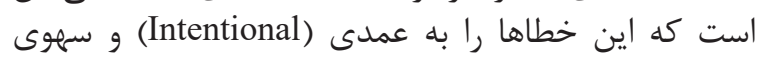

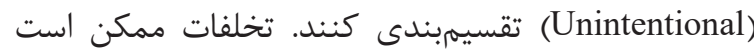

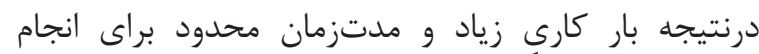

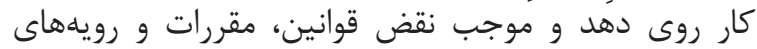

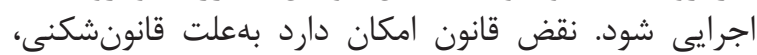

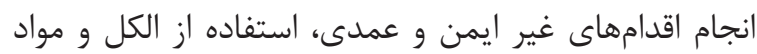

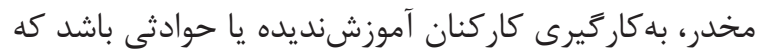

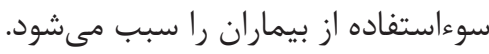

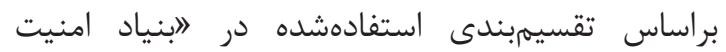

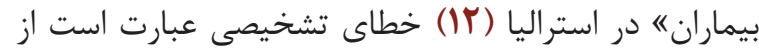

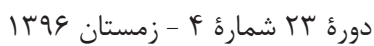

الف- زمانى كه اقدامها و فعاليتهاى تشخيصى انجامشده

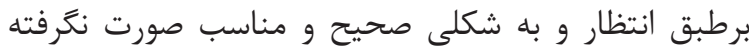
باشد.

ب- زمانى كه اقدام يا عمل تشخيصى انجامشده از ابتدا، يايه و اساس صحيح و مناسبى نداشته باشد.

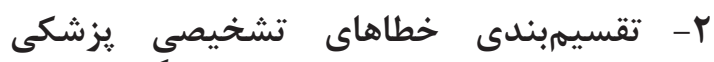
بر اساس مراحل بروز خطا تلبمى

در اين تقسيمبندى، دو مرحله بروز خطا وجود دارد؛ مرحله دانشى و مرحلة بينشى و رفتارى (س) (I). الف - خطاهاى تشخيصى در مرحلة دانشى

خطاهاى تشخيصى در مرحلة دانشى در در هنغام

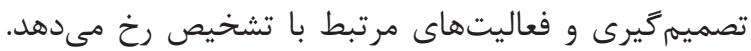

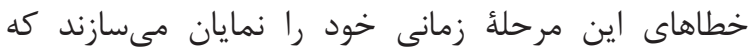

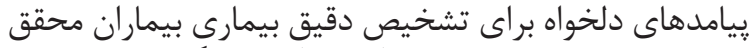

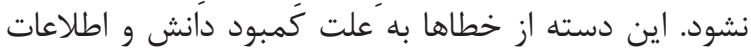

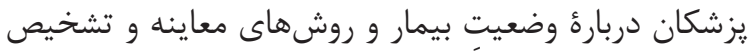

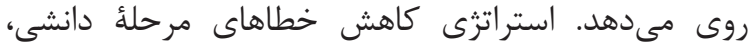

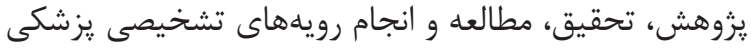

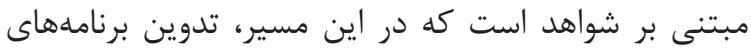

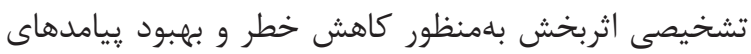

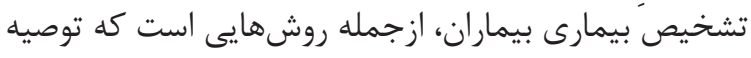
مى شود. خطاهاى مرحلئ دانشى ممكن است به بيماران آسيب بزند

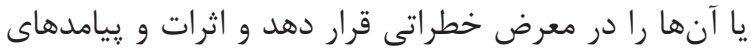

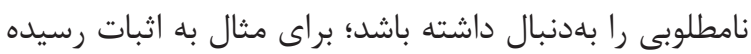

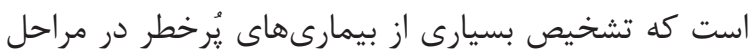

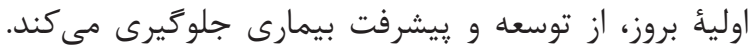

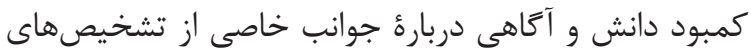

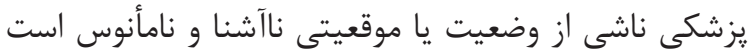
كه انجامدهند

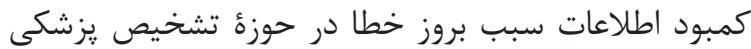

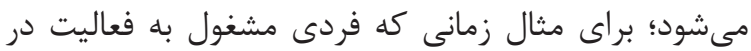

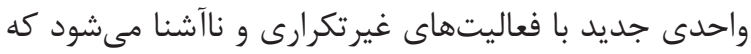
آموزش كافى براى آن نديده است، متعاقب آن آن با مشكلات فئنات

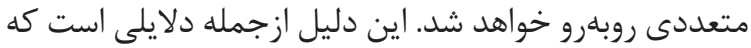

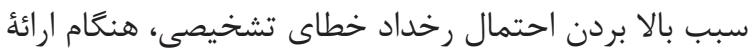

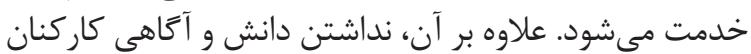

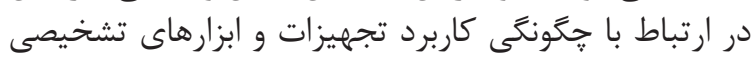
نيز سبب بروز خطاهاى تشخيصى در تشخيص بئي بيمارى بيمار

$$
\text { مى شود. }
$$

\section{ب- خطاهاى مر حلهُ بينشى و رفتارى (اجرا):}

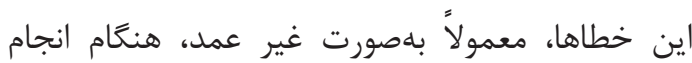

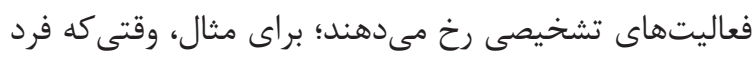

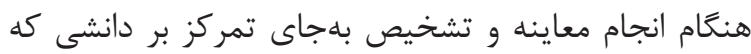

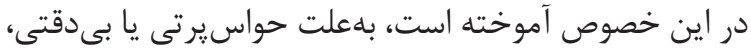

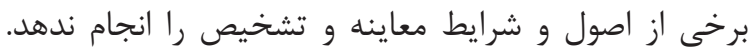




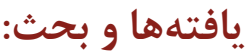

خطاهاى شناختى به دلايل مختلفى ممكن است بروز كند؛

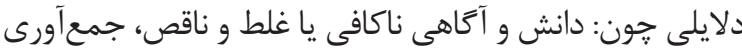

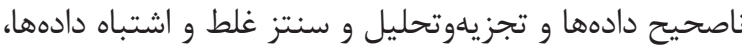

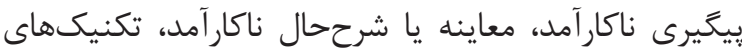

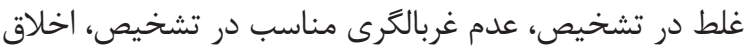

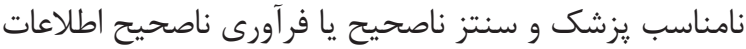

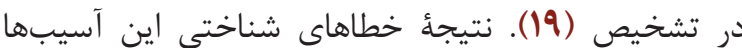

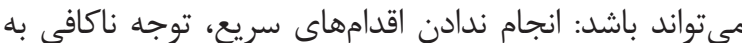

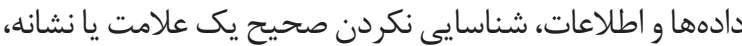

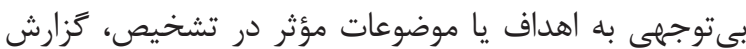

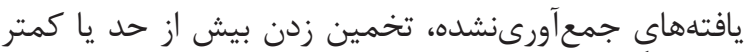

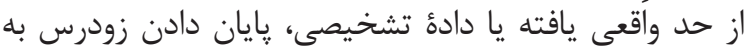

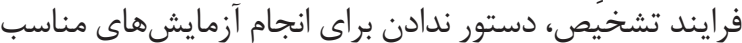

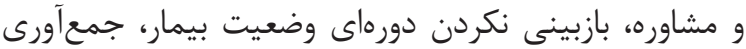

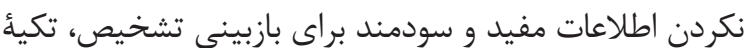

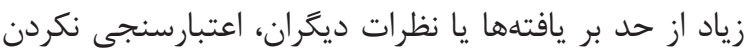

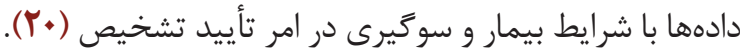

\section{ه- بررسى ميزان خطاهاى تشخيصى ثزشكى:}

در اين بررسى كه مبتنى بر مطالعأ كتابخانهاى اسنادى

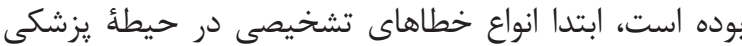

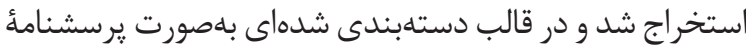

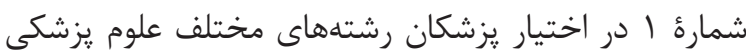

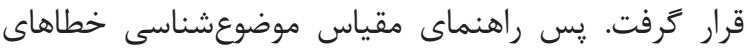

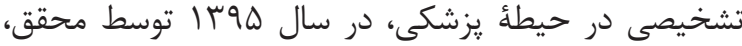

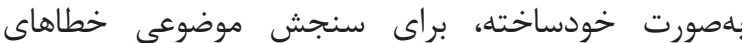
تشخيصى در حيطؤ يزشكى آماده شده است.

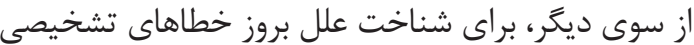

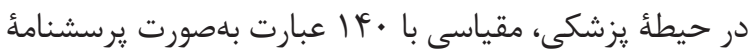

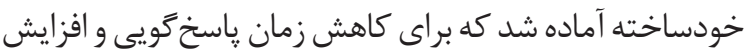

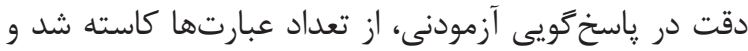

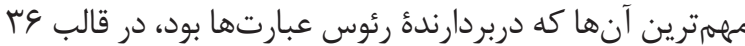

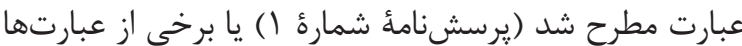

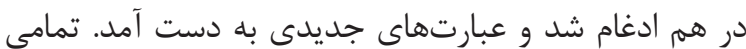

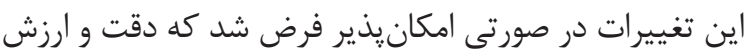

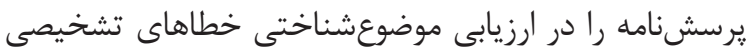

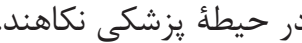

خطايى كه بهطور سهوى به تأخير افتاده درحالى كه در همان

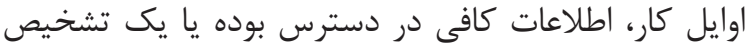

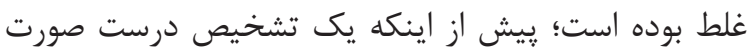

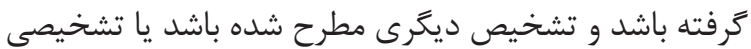

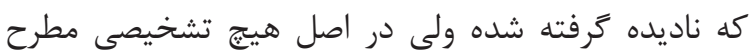

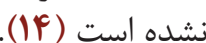

براى شناخت موضوعى خطاهاى يزشكى درئ در مرحلئ

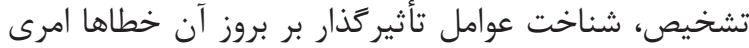

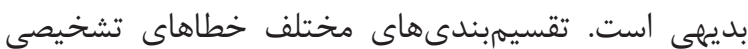

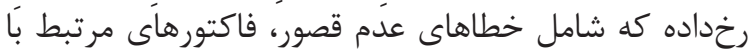

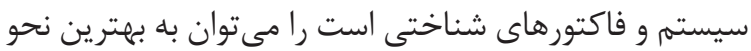

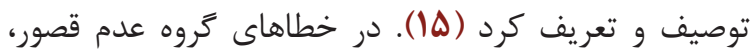

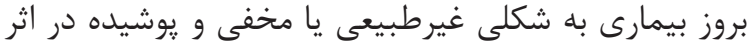
خطا در تشخيص و خطاهاى تشخيصى ناشى از تشئي تشخيص بيمارى مطرح است.

در خطاهاى مرتبط با سيستم نيز اشكالهاى تكنيكى

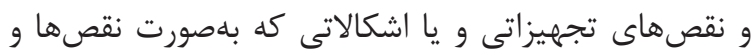

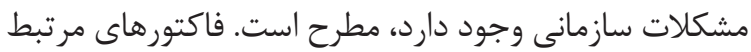

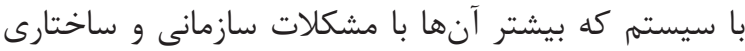

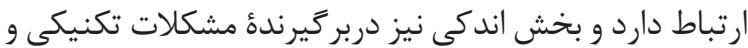

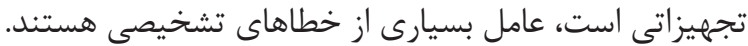

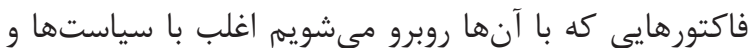

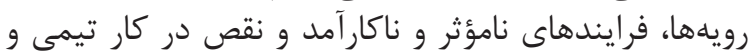

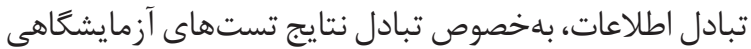

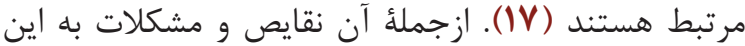

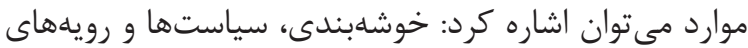

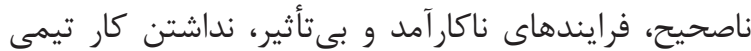

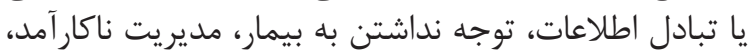

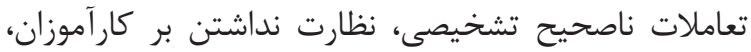

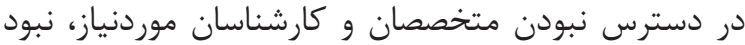

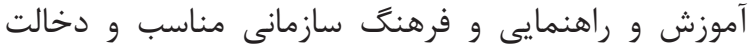

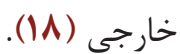

يرسشنامهُ ا. انواع خطاهاى تشخيصى در حيطة يزشكى

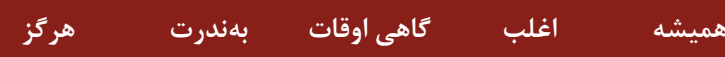

\begin{tabular}{|c|c|}
\hline انش ناكافى معاينه كننده نسبت به وضعيتِ موجود بيمار & 1 \\
\hline همكارى نكردن بيمار در ارائٔ اطلاعات صحيح و كامل & r \\
\hline استفاده نكردن از آزمايشها و مشاورههاى بيمار & r \\
\hline جمع آورى نامناسب اطلاعات بيمار در معاينه و مصاحبه & f \\
\hline انجام ناصحيح معاينه & $\Delta$ \\
\hline انجام ندادن اقدامات غربالكرى لازم (انيكاسيوندار) & 9 \\
\hline
\end{tabular}




\section{تعامل ناكافى يزشك با بيمار يا همراهان او}

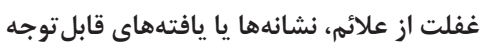

توجه كافى نداشتن به قوانين ساده معاينه و تشخيص

9

استفادة بيش از حد از قوانين در شرايط غيرطبيعى نواني

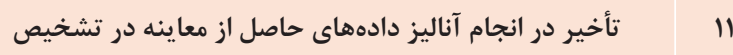

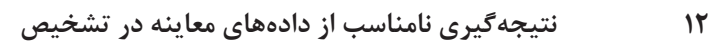

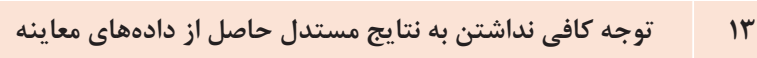

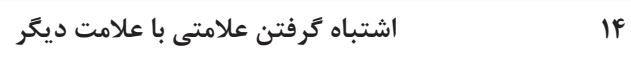

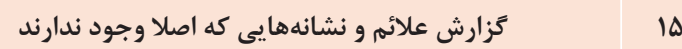

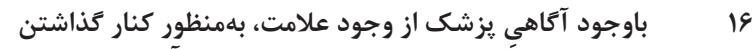

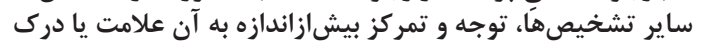
نكردن آن

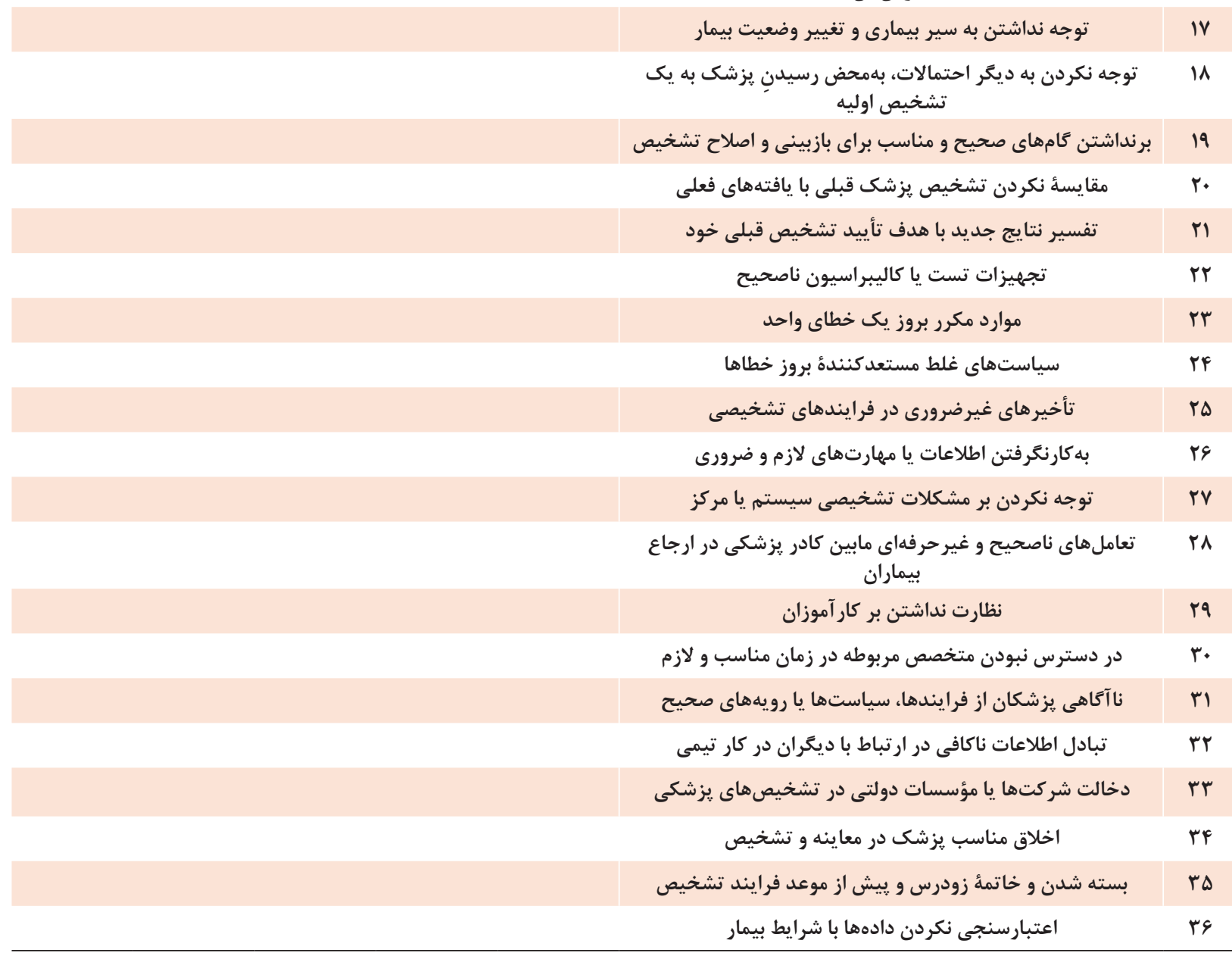

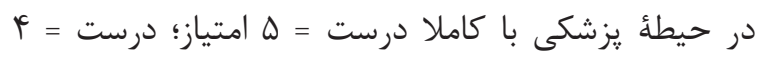

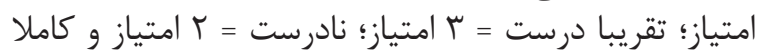

$$
\text { نادرست = ا امتياز تقريبا درسيت تعيين شد. }
$$

در بررسى كيفى علل بروز خطاهاى تشخيصى يزشكى، نُشي،

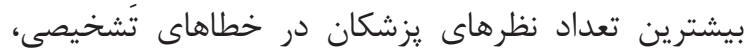

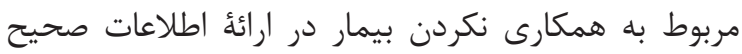

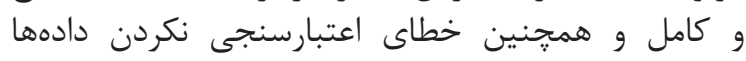

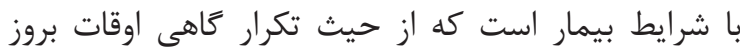

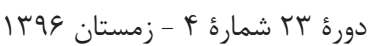

در يرسشنامهٔ دوم نيز براساس اولويتهايى كه يزشكان

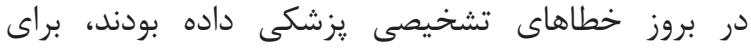
صحتسنجى آزمون اول و تعيين اولويتهاي تشيى اصلى برى بروز

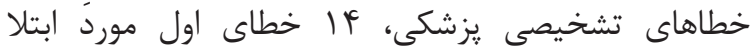

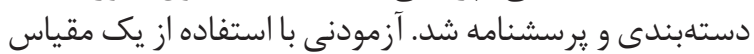

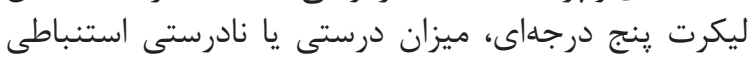

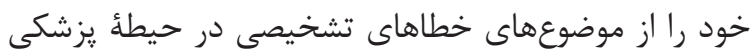

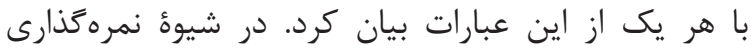

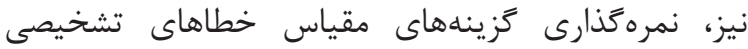




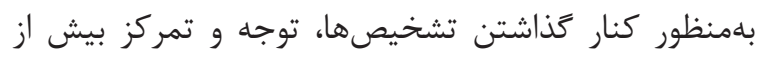

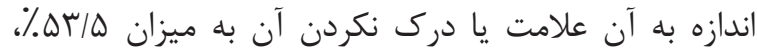

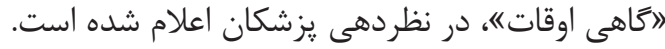
خطاى بهمحض رسيدن يزشك به يك تشخيص اوليه،

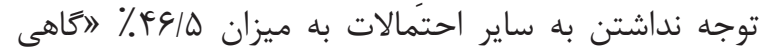

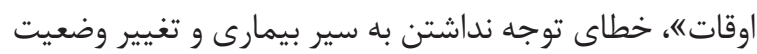

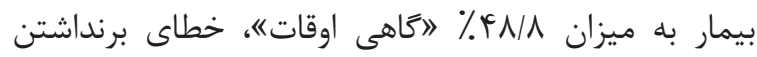

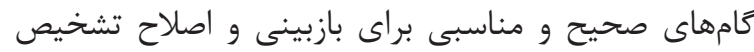

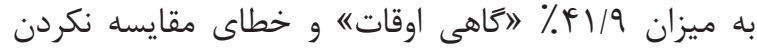

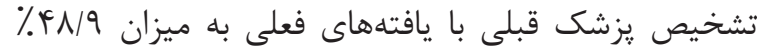

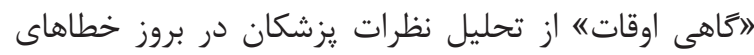

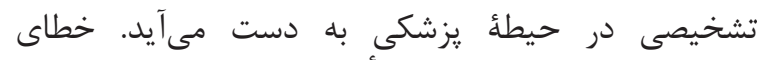

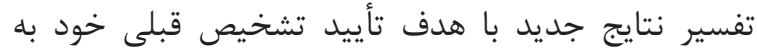

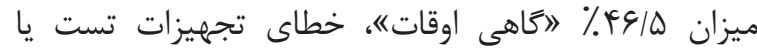

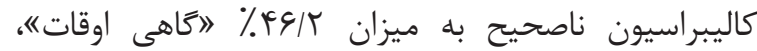

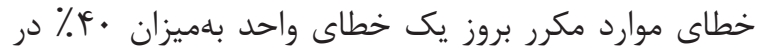

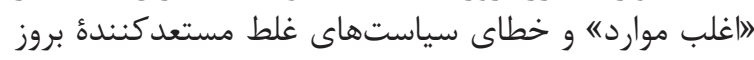

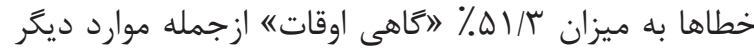

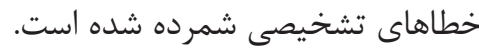

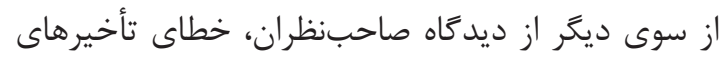

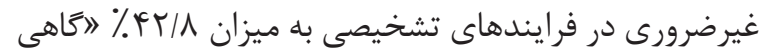

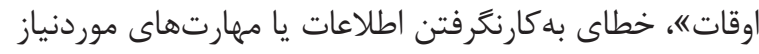

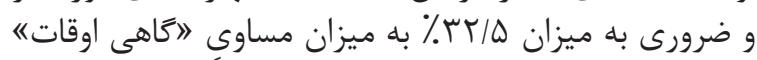

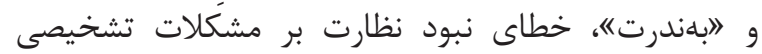

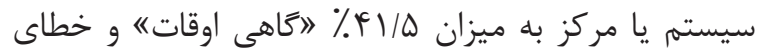

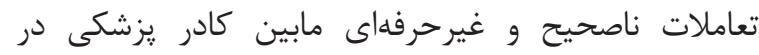

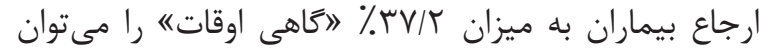

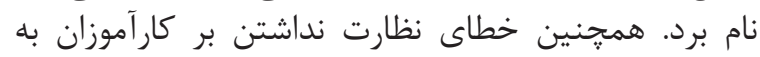

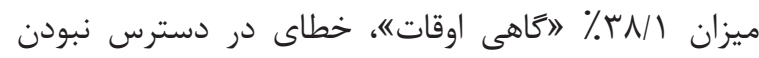

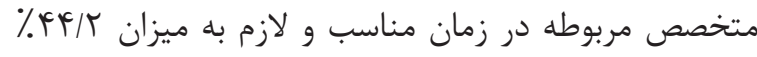

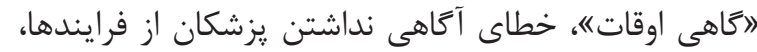

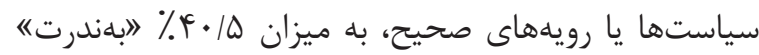

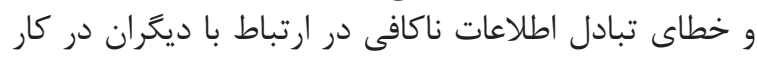

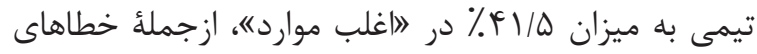
تشخيصى برشمرده شده است. خطاى درئ دخالت شركتهان

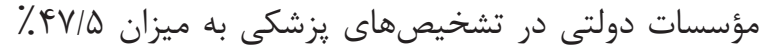

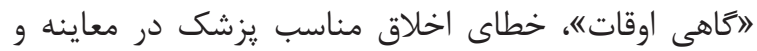

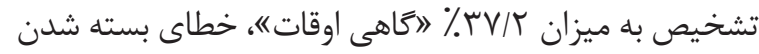

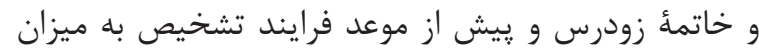

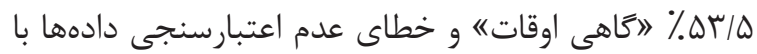

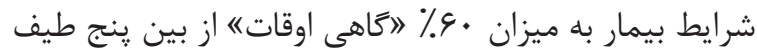

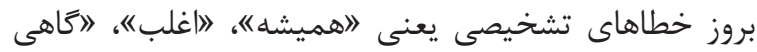

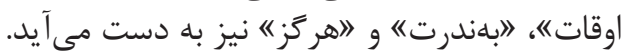

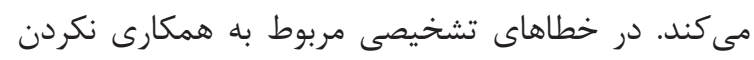

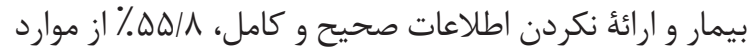

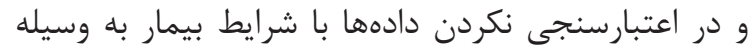

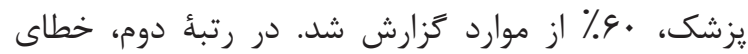

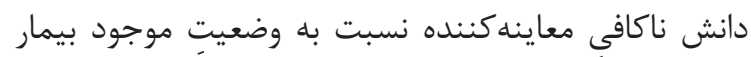

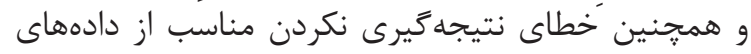

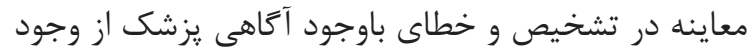

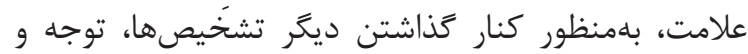

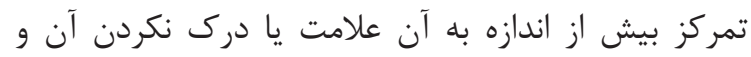

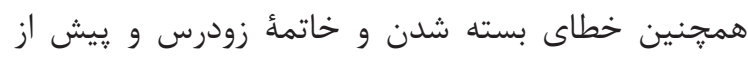

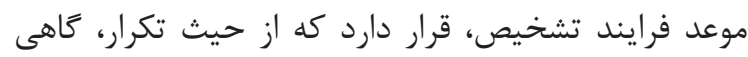

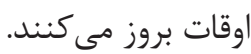

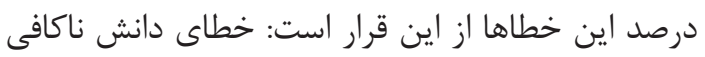

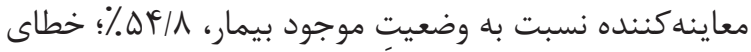

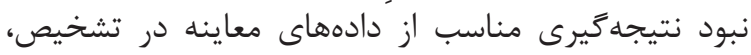

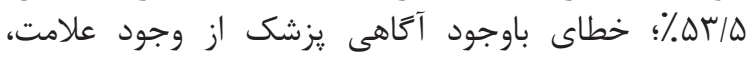

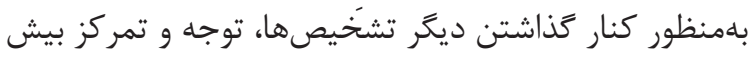

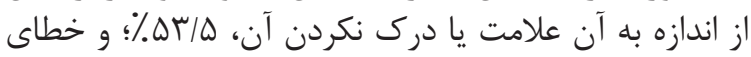

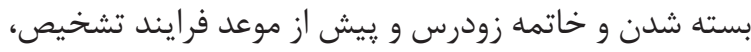

\% \%

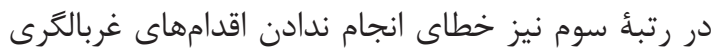

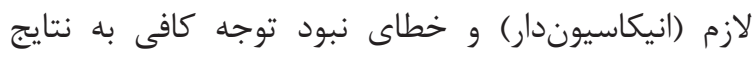

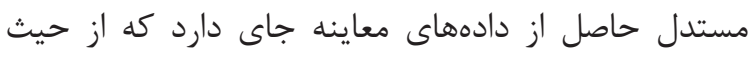

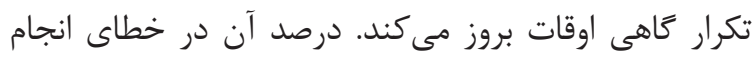

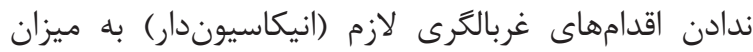

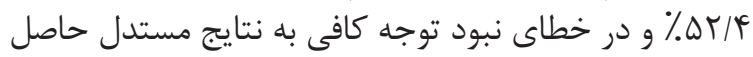

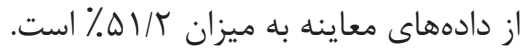

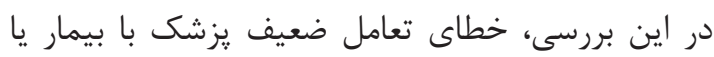

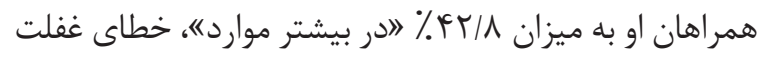

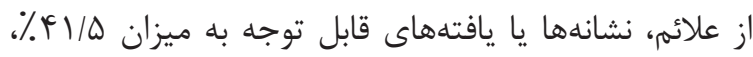

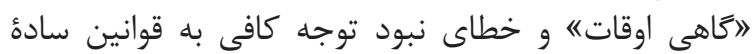

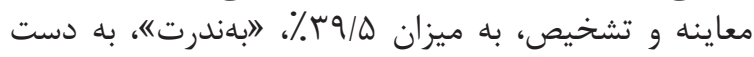

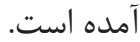

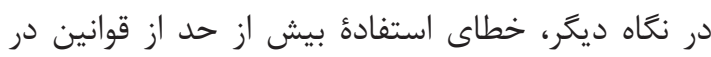

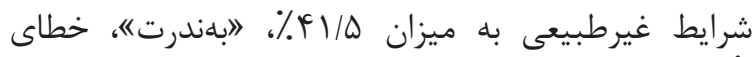

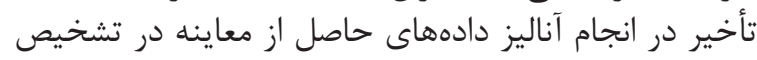

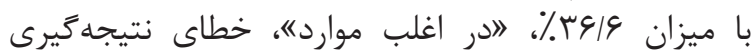

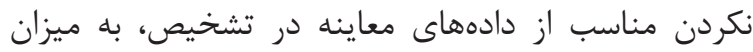

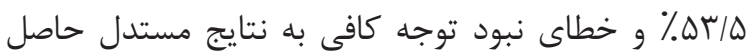

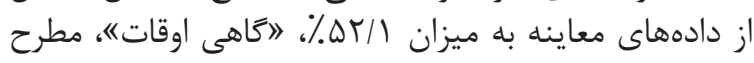

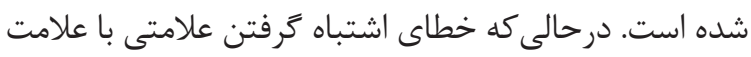

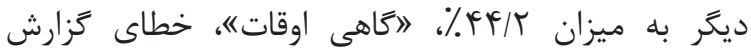

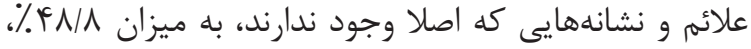

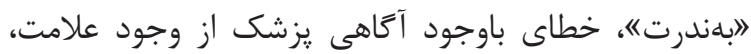


״برسشنامه r. اولويتهاى يزشكان در بروز خطاهاى تشخيصى زيزشى

\begin{tabular}{|c|c|c|c|c|c|c|}
\hline 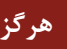 & 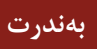 & تَاهى اوقات & 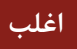 & 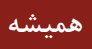 & 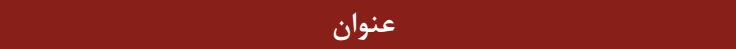 & رديف \\
\hline 1 & 9 & זץ & 9 & - & دانش ناكافى معاينه كننده نسبت به وضعيتِ موجود بيمار & 1 \\
\hline- & 4 & tr & $1 \cdot$ & r & همكارى نكردن بيمار در ارائٔ اطلاعات صحيح و كامل & $r$ \\
\hline 1 & If & IV & $\wedge$ & $r$ & استفاده نكردن از آزمايشها و مشاورههاى بيمار & r \\
\hline- & $\wedge$ & IV & IT & $\Delta$ & جمع آورى نامناسب اطلاعات بيمار در معاينه و مصاحبه & p \\
\hline 1 & 9 & 11 & 11 & f & 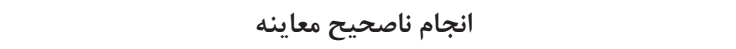 & $\Delta$ \\
\hline- & if & tr & 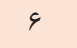 & - & انجام ندادن اقدامات غربالكرى لازم (انيكاسيوندار) & 9 \\
\hline t & 4 & ir & 11 & r & تعامل ناكافى يزشك با بيمار يا همراهان او & $\vee$ \\
\hline 1 & 9 & iv & $\Delta$ & 9 & غفلت از علائم، نشانهها يا يافتههاى قابلتوجه & $\wedge$ \\
\hline 1 & iv & it & 11 & r & توجه كافى نداشتن به قوانين ساده معاينه و تشخيص & 9 \\
\hline r & IV & 10 & f & r & استفادهُ بيش از حد از قوانين در شرايط غيرطبيعى & 1. \\
\hline 1 & If & 11 & 10 & - & تأخير در انجام آناليز دادههاى حاصل از معاينه در تشخيص & 11 \\
\hline- & $\Delta$ & r & Ir & r & نتيجه كيرى نامناسب از دادههاى معاينه در تشخيص & ir \\
\hline- & $\checkmark$ & tr & Ir & 1 & توجه كافى نداشتن به نتايج مستدل حاصل از دادههاى معاينه & ir \\
\hline r & IT & 19 & $\checkmark$ & r & اشتباه گرفتن علامتى با علامت ديخر & If \\
\hline 4 & $r \cdot$ & $1 \cdot$ & r & r & كزارش علائم و نشانههايى كه اصلا وجود ندارند & 10 \\
\hline$r$ & 11 & זr & 4 & - & 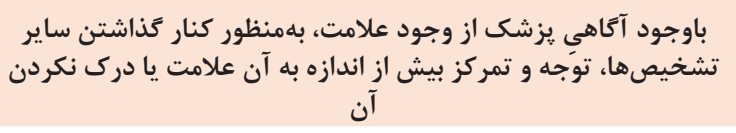 & 19 \\
\hline- & $1 \cdot$ & $r \cdot$ & ir & - & توجه نكردن به سير بيمارى و تغيير وضعيت بيمار & iv \\
\hline$r$ & 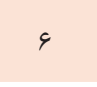 & r. & IT & 1 & 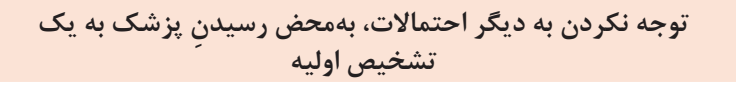 & 11 \\
\hline 1 & $\Lambda$ & 11 & 11 & $\Delta$ & برنداشتن كامهاى صحيح و مناسب براى بازبينى و اصلاح تشخيص & 19 \\
\hline- & iv & $r \mid$ & $\Delta$ & - & مقايسه نكردن تشخيص يزشك قبلى با يافته هاى فعلى & $r \cdot$ \\
\hline- & 11 & $r$. & 11 & 1 & تفسير نتايج جديد با هدف تأييد تشخيص قبلى خود & rI \\
\hline t & ir & 11 & r & r & تجهيزات تست يا كاليبراسيون ناصحيح & rt \\
\hline$\Delta$ & 19 & 11 & $\Delta$ & 1 & موارد مكرر بروز يك خطاى واحد & r \\
\hline t & 9 & rI & c & r & سياستهاى غلط مستعدكنندهُ بروز خطاها & rF \\
\hline 1 & $\checkmark$ & 11 & it & f & تأخير هاى غيرضرورى در فرايندهاى تشخيصى & $r \Delta$ \\
\hline- & Ir & 11 & it & r & به كارنگرفتن اطلاعات يا مهارتهاى موردنياز و ضرورى & re \\
\hline- & $\varepsilon$ & IV & If & f & نبود نظارت بر مشكلات تشخيصى سيستم يا مركز & rv \\
\hline t & 9 & 19 & it & f & تعاملات ناصحيح و غيرحرفهاى مابين كادر يزشكى در ارجاع بيماران & $r \wedge$ \\
\hline f & $\wedge$ & 19 & 11 & r & نظارت نداشتن بر كار آموزان & rq \\
\hline t & 9 & 19 & 11 & r & در دسترس نبودن متخصص مربوطه در زمان مناسب و لازم & r. \\
\hline$r$ & iv & 11 & $1 \cdot$ & - & ناآتاهى يزشكان از فرايندها، سياستها يا رويههاى صحيح & ו \\
\hline 1 & $\checkmark$ & 19 & iv & - & تبادل اطلاعات ناكافى در ارتباط با ديكران در كار تيمى & rt \\
\hline \& & 11 & 19 & r & 1 & دخالت شركتها يا مؤسسات دولتى در تشخيصهاى يزشكى & 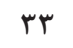 \\
\hline r & 1 . & 19 & $1 \cdot$ & r & اخلاق مناسب يزشك در معاينه و تشخيص & rF \\
\hline 1 & 11 & r & $\wedge$ & - & بسته شدن و خاتمهُ زودرس و پيش از موعد فرايند تشخيص & ra \\
\hline 1 & $1 \cdot$ & re & f & 1 & اعتبارسنجى نكردن دادهها با شرايط بيمار & rq \\
\hline
\end{tabular}




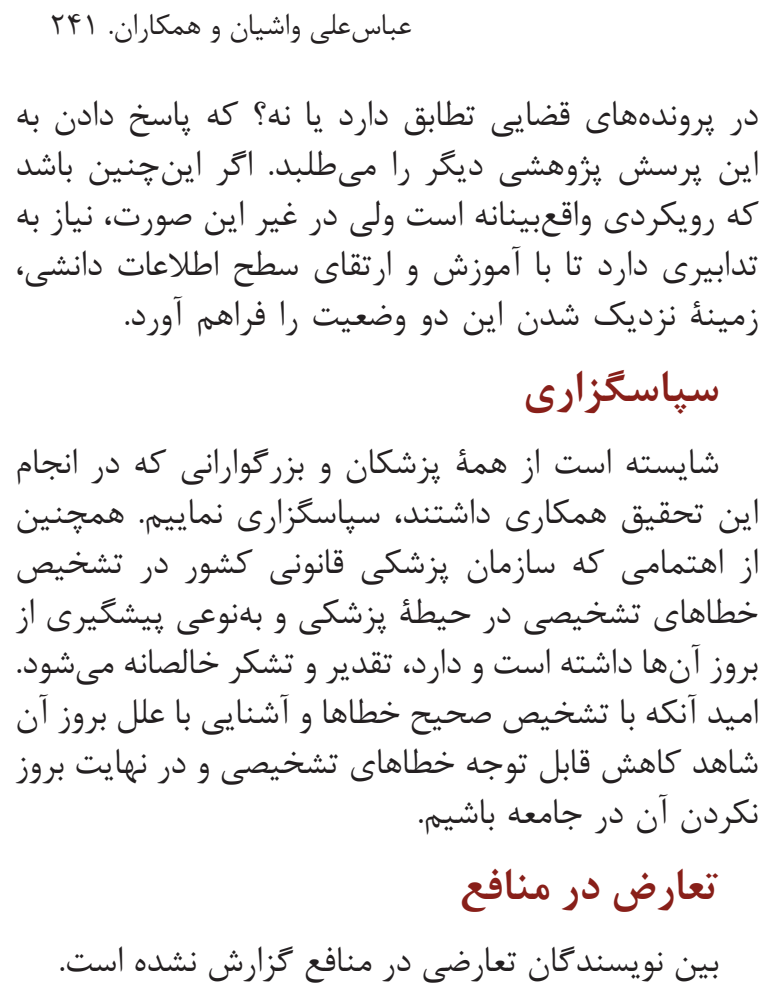

\section{References}

1. Rafihzade Tabaeezavare M, Hajmanochehre R, Nasajezavare M. Frequency of Failure of General Physicians in Referral Complaints to the Forensic Medicine Commission of Tehran from 1382 to 1384. Ir J Forensic Med. 2008;13(3):152-7.

2. A crime in case of retaliation or a deed is the result of a documentary evidence of the perpetrator's behavior, whether it is executed in a steady manner or in the form of an appeal to the community.

3. Gharashi AA. Ghamoose Qouran.Tehrn: Darol kotobel eslame. 1988;2:258.

4. Mostafavi H. Altahghigh fe kalemat el qouran el karim. Tehran: Mostafavi Publishing Center Work.2007;3:78.

5. Amid dictionary.Tehran:Meelad.1391.

6. Hajihoseine AA. Engineering human errors.Tehran:Fanavaran.1394.p18.

7. Vashian AA. Medical liability. Qom: University of Medical Sciences.1396.p32.

8. Joint commission on the Accreditation of Health care organizations(JCAHO).
نتيجه

1 - بيشتر يزشكان بر آنند كه بروز خطاهاى تشخيصى به

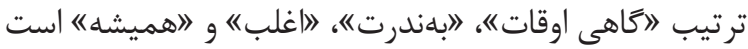

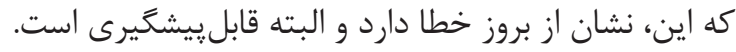

r- در تحليل نظرات يزشكان، خطاهاى تعامل ناكافى

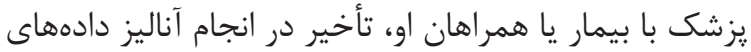

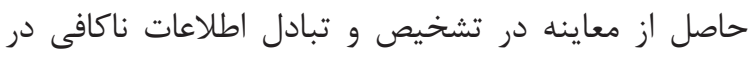

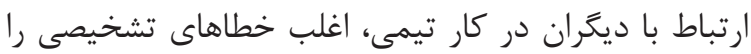

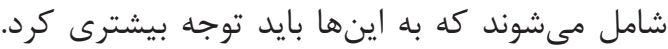

r- برخى از خطاهاى تشخيصى كه بلندرت بروز مى كنند

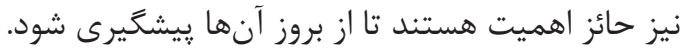

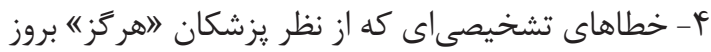

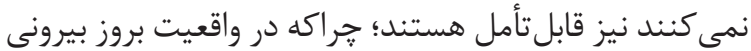

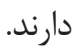

ه- بهتر است به دنبال اين واقعيت باشيم كه آيا نظر

يزشكان در خصوص علل بروز خطاهاى تشخيصى در حيطه يزشكى با وضعيت موجود خطاهاى تشخيصى در در اين حيطه
9. Dehkhoda AA. Dehkhoda Dictionary. Tehran: Tehran University. 1377.The Following word recognition.

10. Moeen M. Moeen Persian Dictionary. The Following word recognition.

11. Amid dictionary. Tehran: Meelad. 1391. The Following word recognition.

12. Graber ML, Franklin N, Gordon R. Diagnostic error in internal medicine. Arch Intern Med. 2005;165(13):1493-9.

13. Vashian AA. Medical Responsibility. Qom University of Medical Sciences. 2017;56.

14. Australian Patient Safety Foundation.University of South Australia, Playford Building, Adelaide SA 5000, Australia.

15. Scheff TJ. Decision rules, types of error, and their consequences in medical diagnosis. Systems Research and Behavioral Science. 1963;8(2):97107. 